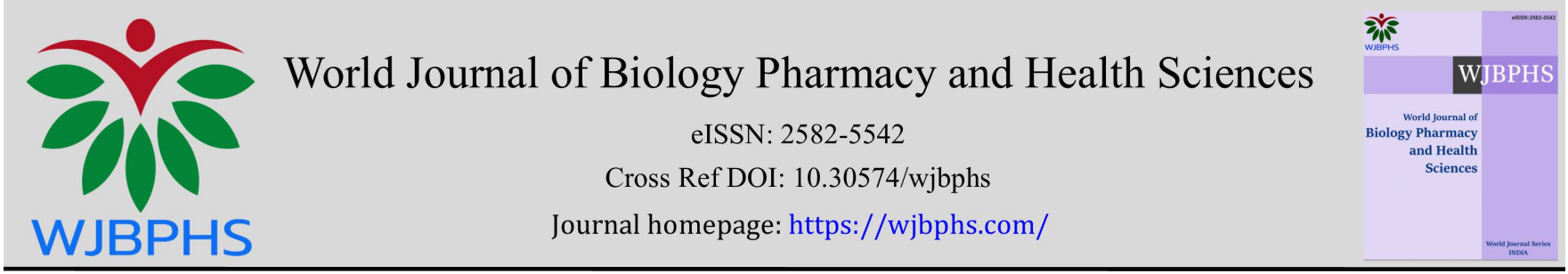

(RESEARCH ARTiCLE)

\title{
Allelopathic effects of Amaranthus viridis L. on some growth characters of Swiss chard
}

\section{plant (Beta vulgaris var. Cicla))}

\author{
Misson F Osman and Elnasri M Mutwali * \\ Department of Biology, Faculty of Education, Alzaiem Alazhari University, Sudan.
}

World Journal of Biology Pharmacy and Health Sciences, 2022, 09(02), 001-004

Publication history: Received on 24 December 2021; revised on 03 February 2022; accepted on 05 February 2022

Article DOI: https://doi.org/10.30574/wjbphs.2022.9.2.0032

\begin{abstract}
A pot experiment was conducted at Faculty of Education, Alzaiem Alazhari University, Sudan, during 2019/2020 to evaluate the effect of Amaranthus viridis powder on the emergence and growth of Swiss chard (Beta vulgaris var. cicla). The experiment was set as a completely randomized design (CRD) with four replicates. In the treatments the powder of Amaranthus viridis was incorporated into the soil at rate of $\left(0,0.5,1.0 .1 .5\right.$ and $2.0 \% \mathrm{w} / \mathrm{w}$ ) representing $\mathrm{T}_{1}$ (control), $\mathrm{T}_{2}$, $\mathrm{T}_{3}, \mathrm{~T}_{4}$ and $\mathrm{T}_{5}$ respectively. Results indicated that Amaranthus viridis powder decrease germination, plant height, number of leaves, leaf area, shoot and root fresh and dry weight, chlorophyll content $(\mathrm{a}, \mathrm{b})$ and some chemical elements $(\mathrm{P}, \mathrm{Ca}$, $\mathrm{Mg}$, Fe) of Swiss chard (Beta vulgaris var. cicla).
\end{abstract}

Keywords: Amaranthus viridis; Swiss chard; Germination; Allelopathy; Chemical constituent

\section{Introduction}

Food shortage and deficiency is considered to be one of the most global problems across the world. Weeds leaf uncontrol may cause great losses in crop yield and these losses exceeded that caused by other pests,

Plants growing together compete with each other for sunlight, soil nutrients and water. To reduce competition, plants produce chemicals that affect the germination and growth of neighbouring plants by disruption of various physiological processes [1]. These chemicals are known as allelochemical which released into the environment by plant organs.

Swiss chard (Beta vulgaris var. cicla) is a vegetable which is consumed by the majority of the Sudanese population. The main constrain of Swiss chard production is the weed infestation. Amaranthus viridis is one of the dominant weeds that compete with Swiss chard and other vegetables.

The present study was conducted to evaluate the effect of Amaranthus viridis on the germination growth, yield and some chemical constituents of Swiss chard (Beta vulgaris var. cicla).

\section{Material and methods}

\subsection{Plant material}

Amaranthus viridis plants were collected fro the farm of the Faculty of Agriculture, University of Khartoum. The plants were uprooted, washed with distilled water than dried at room temperature $\left(25^{\circ} \mathrm{C}\right.$ for 96 hours. Plant then chopped and ground into fine powder. The Swiss chard seeds were obtained from local market (local cultivar).

\footnotetext{
* Corresponding author: Elnasri M Mutwali

Department of Biology, Faculty of Education, Alzaiem Alazhari University, Sudan.

Copyright $(2022$ Author(s) retain the copyright of this article. This article is published under the terms of the Creative Commons Attribution Liscense 4.0.
} 


\subsection{Pot experiment}

Plastic pots $(18 \times 30 \mathrm{~cm})$ filled with silt soil, were arranged in completely randomized design (CRD) with four replications. Five treatments were used, the first one $\mathrm{T}_{1}$ representing the control where the soil was from Amaranthus residue. The other four treatments were represented by $\mathrm{T}_{2}, \mathrm{~T}_{3}, \mathrm{~T}_{4}$ and $\mathrm{T}_{5}$, where soils were incorporated with Amaranthus powder in 10, 20, 30 and 40 g per pot which representing 0.5, 1.0, 1.5 and 2.0\% w/w residue (soil0 respectively. Five seeds of Swiss chard were sown in reach pot and later thinned to two seedlings. Pots were irrigated daily with tap water. During the experiment the germination percentage, plant height, numbers of leaves, leaf area were recorded. At the end of the experiment shoot and root fresh and dry weight, chlorophyll content (a, b) and some elements ( $\mathrm{P}, \mathrm{Ca}, \mathrm{Mg}, \mathrm{Fe}$ ) were variance (ANOVA) according to [2].

\section{Results and discussion}

The germination percentage of Swiss chard plant decreased as the concentration of Amaranthus viridis increased (Table 1). The reduction of germination percentage was from $83.33 \%$ at control to $46.65 \%$ at treatment $\mathrm{T}_{2}$ then decreased to $6.60 \%$ and $3.33 \%$ at treatments $\mathrm{T}_{3}$ and $\mathrm{T}_{4}$ respectively. These results were supported by the findings of [3] who reported that Amaranthus viridis extract significantly decreases the germination of mung bean (Vigna radiata (L.) R. Wilczek). Similar results were reported by [4] they found that the extracts of the whole plant of Amaranthus exhibited severe inhibition of seed germination of tomato as well as of weed seeds of Conyza bonariensis. Also[ 5]) concluded that leaf leachates of Amaranthus viridis, Parthenium hysteroporus and Polygonum plebeinum significantly inhibited the growth of Triticum aestivum. The inhibition in the germination percentage of Swiss chard may be attributed to the presence of phenolic acids. These phenolic acids may inhibit cell division, water and nutrient uptake and consequently germination.

The highest plant height of Swiss chard was observed at control $14.16 \mathrm{~cm}$, then decreased to 10.20,10.00, 9.50 and 8.80 $\mathrm{cm}$ in treatments $\mathrm{T}_{2}, \mathrm{~T}_{3}, \mathrm{~T}_{4}$ and $\mathrm{T}_{5}$ respectively. These results were confirmed by the findings of [6] who reported that extracts of Amaranthus viridis decreased shoot growth of rye grass compared to control. Similar results were reported by [7] who found that incorporation of powder residue Amaranthus viridis in the soil significantly decreased plant height of common bean (Phaseolus vulgaris L.) cow pea (Vigna sinensis (L.) Walp), pigon pea (Cajanus cajan (L.) Mill sp) and alfalfa (Medicago sativa L.).

Table 1 Allelopathic effect of Amaranthus viridis residue powder on germina-tion, plant height, number of leaves and leaf area of Swiss chard)

\begin{tabular}{|l|c|c|c|c|}
\hline Treatments & Germination (\%) & Plant height (cm) & Number of leaves & Leaf area (cm $\left.{ }^{2}\right)$ \\
\hline $\mathrm{T}_{1}($ control) & 83.33 & 14.10 & 4.20 & 8.44 \\
\hline $\mathrm{T}_{2}(0.5 \% \mathrm{w} / \mathrm{w})$ & 46.66 & 10.20 & 4.00 & 8.30 \\
\hline $\mathrm{T}_{3}(1.0 \% \mathrm{w} / \mathrm{w})$ & 6.60 & 10.00 & 4.00 & 8.08 \\
\hline $\mathrm{T}_{4}(1.5 \% \mathrm{w} / \mathrm{w})$ & 3.33 & 9.50 & 4.00 & 8.00 \\
\hline $\mathrm{T}_{5}(2.0 \% \mathrm{w} / \mathrm{w})$ & 0.00 & 8.80 & 3.60 & 7.56 \\
\hline $\mathrm{LSD}$ & 1.40 & 1.82 & 0.64 & 0.23 \\
\hline
\end{tabular}

The number of leaves did not show any significant difference between treatment and control, although some researchers reported a significant decrease in number of leaves of sorghum, millet, maize and wheat. The leaf area of Swiss chard exhibited significant decrease from the control at treatments $\mathrm{T}_{3}(1 \%, \mathrm{w} / \mathrm{w}), \mathrm{T}_{4}(1.5 \%, \mathrm{w} / \mathrm{w}) \mathrm{and} \mathrm{T}_{5}(2 \%$, $\mathrm{w} / \mathrm{w}$ ) (Table 1). Similar results were reported by [8] who showed that irrigation of groundnut and maize with water extract of Eucalyplus globulus reduced leaf area.

The shoot fresh and dry weight of Swiss chard exhibited a significant decrease in all treatments as compared with control (Table 2). These results were supported by the results of [9] who found that Amaranthus hybiridus inhibited the dry weight of shoot and root of red clover and root of alfalfa. In connection to this [10] assumed that decrease in fresh and dry weight may be attributed to allelochemicals inhibiting protein and carbohydrate synthesis and hence reducing seedling growth.

The root length, root fresh and dry weight showed a significant decrease from control (Table 2). The root length decrease as the concentration increased. 
Table 2 Allelopathic effect of Amaranthus viridis residue powder on shoot fresh weight, shoot dry weight, root length, root fresh weight and root dry weight of Swiss chard

\begin{tabular}{|l|c|c|c|c|c|}
\hline \multicolumn{1}{|c|}{ Treatments } & $\begin{array}{c}\text { Shoot fresh } \\
\text { weight (g) }\end{array}$ & $\begin{array}{c}\text { Shoot dry } \\
\text { weight (g) }\end{array}$ & $\begin{array}{c}\text { Root length } \\
\text { (cm) }\end{array}$ & $\begin{array}{c}\text { Root fresh } \\
\text { weight (g) }\end{array}$ & $\begin{array}{c}\text { Root dry } \\
\text { weight (g) }\end{array}$ \\
\hline $\mathrm{T}_{1}($ control) & 0.96 & 0.45 & 6.90 & 0.61 & 0.31 \\
\hline $\mathrm{T}_{2}(0.5 \% \mathrm{w} / \mathrm{w})$ & 0.70 & 032 & 4.90 & 0.52 & 0.24 \\
\hline $\mathrm{T}_{3}(1.0 \% \mathrm{w} / \mathrm{w})$ & 0.65 & 0.30 & 4.30 & 0.40 & 0.20 \\
\hline $\mathrm{T}_{4}(1.5 \% \mathrm{w} / \mathrm{w})$ & 0.47 & 0.20 & 3.60 & 0.50 & 0.16 \\
\hline $\mathrm{T}_{5}(2.0 \% \mathrm{w} / \mathrm{w})$ & 0.30 & 0.15 & 3.00 & 0.22 & 0.16 \\
\hline $\mathrm{LSD}$ & 0.14 & 0.00 & 0.92 & 0.00 & 0.00 \\
\hline
\end{tabular}

Table 3 Allelopathic effect of Amaranthus viridis residue powder on chlorophyll content and some chemical elements Swiss chard

\begin{tabular}{|c|c|c|c|c|c|c|}
\hline \multirow{2}{*}{ treatments } & \multicolumn{2}{|c|}{ Chlorophyll } & \multirow{2}{*}{$P(\mathrm{mg} / \mathrm{kg})$} & \multirow{2}{*}{$\begin{array}{c}\mathrm{Ca} \\
(\mathrm{mg} / \mathrm{kg})\end{array}$} & \multirow{2}{*}{$\begin{array}{c}\mathrm{Mg} \\
(\mathrm{mg} / \mathrm{kg})\end{array}$} & \multirow{2}{*}{$\begin{array}{c}\text { Fc } \\
(\mathrm{mg} / \mathrm{kg})\end{array}$} \\
\hline & $\mathrm{a}(\mathrm{mg} / \mathrm{g})$ & $\mathrm{b}(\mathrm{mg} / \mathrm{g})$ & & & & \\
\hline $\mathrm{T}_{1}$ (control) & 375.43 & 152.16 & 920 & 2400 & 2520 & 1952 \\
\hline $\mathrm{T}_{2}(0.5 \% \mathrm{w} / \mathrm{w})$ & 353.65 & 146.65 & 122 & 2400 & 240 & 1174 \\
\hline $\mathrm{T}_{3}(1.0 \% \mathrm{w} / \mathrm{w})$ & 242.75 & 109.30 & 102 & 2300 & 600 & 1531 \\
\hline $\mathrm{T}_{4}(1.5 \% \mathrm{w} / \mathrm{w})$ & 318.76 & 129.13 & 99 & 2200 & 960 & 1329 \\
\hline $\mathrm{T}_{5}(2.0 \% \mathrm{w} / \mathrm{w})$ & 350.24 & 148.24 & 93 & 2300 & 1520 & 1496 \\
\hline LSD & 4.06 & 3.03 & 2.69 & 44.61 & 51.57 & 2.69 \\
\hline
\end{tabular}

Root growth is characterized by high metabolic rate and for this reason; roots are highly susceptible to environmental stresses such as allelochemicals in soil [11]. These results were supported by the results of [7]) who reported that the incorporated powder of Amaranthus viridis into soil decreased root length as well as root fresh and dry weight of sorghum, millet, maize and wheat. The decrease in root fresh and dry weight of Swiss chard may be attributed to the decrease in root and shoot seedling length which induced by allelochemicals found in Amaranthus powder.

The chlorophyll content (a,b) decreased significantly as the concentration of Amaranthus increased (Table 3). Similar results were reported by [12] and [13] who reported that a reduction was observed in chlorophyll (a) content of the corn treated with Eucalyptus rostrata leaf residue. In this respect [14] attributed the decrease in chlorophyll content to the decreases in the relative water content of leaves which initially induce stomatal closure, imposing a decrease in the supply of $\mathrm{Co}_{2}$ to the mesophyll cells and consequently, photosynthesis could be lowered resulting in the decrease in chlorophyll content.

A significant reduction was observed in content of phosphorus $\mathrm{P}$ and calcium $\mathrm{Ca}$, Magnesium, Mg and iron Fe in treatments as compared with control (Table 3). The reduction in P content was also reported by [13] who found that Eucalyptus allelochemicals reduced the amount of $\mathrm{P}$ and $\mathrm{N}$. On the other hand, the decrease in $\mathrm{Ca}^{2+}, \mathrm{Mg}^{2+}$ and Fe ${ }^{2+}$ was supported by[15] who observed that root exudates of cucumber inhibited the uptake of $\mathrm{K}^{+}, \mathrm{Ca}^{2+}, \mathrm{Mg}^{2+}$ and $\mathrm{Fe}^{2+}$ by cucumber seedlings. The reduction in these elements may be attributed to that, root membranes are primary site of action for allelochemicals and the contact of phenolic acid with the root cell membrane leads to depolarization, an efflux of ions and a reduction of hydrolic conductivity, water uptake and net nutrient uptake [16].

\section{Conclusion}

The study concluded that Amaranthus viridis residue containing phenolic compunds suppress the germination, the growth and yield of Swiss chard. Field studies are needed to evaluate the suppressive efficacy of Amaranthus viridis under natural conditions. 


\section{Compliance with ethical standards}

\section{Acknowledgments}

The authors would like to thank the Central Lab of University of Khartoum (Shambat) for the assistance in chemical analysis and the Biology Department, Faculty of Education, Azaiem Alazhari University.

\section{Disclosure of conflict of interest}

Authors have declared that no competing interests exist.

\section{References}

[1] Soltys D, Krasuska U, Boagatekk R, Gniazdowska A. Allelochemicals as biocherbicides-present and perspectifes. V: Herbicides-current research and case studies in use price A.J., Kelton, J.A. (Eds.). In Tech Publisher, Rijeka, Croatica. 2013; 51-54.

[2] Gomez AK, Gomez AA. Statistical procedures for agricultural research, John Willey and Sons, Inc. Canada. 1984.

[3] Sheeba MA, Mahesh B, Devichinmayee M, Swapna TS, Mini I. The allelopathic potential of the weed Amaranthus viridis L. on germination and pigment profile of a pulse crop Vigna radiata (L.) R. Willsczek. J. Aqu. Biol. Fish. 2014; $2: 3344-3350$.

[4] Gerhard Prinsloo, Christian phillipus Du Plooy. The allelopathic effects of Amaranthus on seed germination, growth and development of vegetables. J. of Biological Agriculture and Horticulture. 2018; 34(4): 268-279.

[5] Dongre PN, Singn AK. Inhibition effects of weeds on growth of wheat seedling. Allelopathy J. 2007; 20: $387-394$.

[6] Shamimasultana, Asaduzzaman M. Allelopathic potential of Amarantus viridis L. against annual ryegrass. Developing solutions to evolving weed problem. 18th Australasian Weeds Conference, Melbourne, Victoria, Australia. 8-11 October 2012; 181-183.

[7] Dafaallah AB, Yousif MH, Abdelrahman AO. Allelopathic effects of pigweed (Amaranthus viridis L.) on seed germination of seedling growth of some lequminous crops. al International Journal of Innovative Approaches in AgriculturResearch. 2019; 3(4): 566-572.

[8] Jayakumar M, Eyini M, Pannirselvam S. Allelopathic effect of Eucalyptus globulus Labil on groundnut and corn. Com.physiol. Ecol. 1990; 5: 109-113.

[9] Kalinova S, Golubinova I, Hristoskov A, Ilieva A. Allelo-pathic effect of aquveous extract from root systems of Johnson grass on seed germination and initial development of soybean, pea and Vetch. Rotar. Pourt. 2012; 49: 250-256.

[10] Wang Q Li, ZH, Ruan X, Pan CD, Jiang DA. Phenolics and plant allelopathy. Molecules. 2010; 15(12): 8933-8952.

[11] Cruz-Ortega R, Anaya AL, Hernandez S, Bautista BE, Laguna Hernandez G. Effect of allelochemical stress produced by Sicyos deppi on seedling root ultrastructure of Phaseolus vulgaris and Cuarbita ficifalsa, J. Chem. Ecol. 1998; 24: 2039-2057.

[12] Yang CM, Lee CN, Chou CH. Effect of three alleopathic phenolics on chlorophyll accumulation of rice seedlings by inhibition of supply orientation. Bot. Bull. Acd. Sinica. 2007; 43: 299-304.

[13] Hegab MM, Gabr MA, Al-Wakeel SAM, Hamed BA. Allelopathic potential of Eucalyptus rostrata leaf residue on some metabolic activities of Zea mays L., Universal J. of Plant Science. 2016; 4(2): 11-21.

[14] Hussain MF, Reigosa MJ. Allelochemical stress inhibits growth, leaf water relations, PSII phytochemistry, nonphotochemical fluorescence quenching and heat energy dissipation in three C3 perenial species. Journal of Experimental Botany. 2011; 2(13): 4533-4545.

[15] Yu JQ, Matsui Y. Effects of root exudates of cucumber (Cucumis sativus) and allelochemicals on ion uptake by cucumber seedling. J. Chem. Ecol. 1997; 23: 817-827.

[16] Bazira Makenga R, Leroux GD, Simard RR. Effect of benzoic acid, cinnanic acds on membrane permeability of soy bean roots. J. Chem. Ecol. 1995; 21: 1271-1285. 